DOI : $10.14746 / p s .2019 .1 .10$

Poznań University of Economics and Business

https://orcid.org/0000-0001-8287-7487

\title{
AFRICAN DIMENSION OF THE BELT AND ROAD INITIATIVE
}

Chinese activity in Africa have a long history (N'Diaye, 2016). From the beginning it has been China that initiated these bilateral contacts, which remains the case today. Since Chinese-African co-operation has considerably intensified, it has recently become the subject of extensive research (Alden, Alao, Zhang, Barber, 2018; Brautigam, 2015; Chen, 2016; Cheng, Taylor, 2017; Conteh-Morgan, 2017; Lin, Wang, 2017; Stahl, 2017; Wekesa, 2016; ZiroMwatela, Changfeng, 2016). Some of these studies examine The Belt and Road Initiative (BRI), the significance of which is to a large extent related to the importance of China in the global economy and politics, and to the role China is forecast to play in the geo-political sphere (Góralczyk, 2018; Kołodko, 2018).

The Chinese presence in Africa goes far beyond what might be suggested by the engagement of some states of the region in the BRI - the initiative which may easily and rapidly expand to encompass further countries in Africa. Even if this does not happen, however, China is most unlikely to reduce current intensive co-operation with its partners in Africa who are formally outside the BRI (Angola, Nigeria, Democratic Republic of Congo, Congo, Guinea, Equatorial Guinea). Nevertheless, the development of the BRI may exert critical influence on China's policy towards Africa, both in strategic and practical terms, such as ensuring the coherence of Chinese policies for Africa. The research purpose of this paper is to examine the role of the BRI in ChinaAfrica relations and the mutual interdependence between the BRI and other forms of Chinese presence in Africa. In order to attain this goal, the method of analysis of secondary data will be employed regarding concluded agreements, trade exchange, Official Development Assistance (ODA), foreign direct investment (FDI), debt, instruments of soft power and plans for the future.

There is a direct connection between the BRI and the economic and foreign policy of the Communist Party of China. The Party announced its intention to reduce state interventionism and enhance market mechanisms at the Third Plenary Session of the $18^{\text {th }}$ Central Committee. The theoretical tenets of this concept may be attractive for China's African partners because China defines the BRI as a public good and presents the Initiative as a new model of governance and integration (Szczudlik, 2016). The ideology behind the Initiative refers to the 'third way,' which some African countries still view as a desirable solution. From the African perspective, the concept has the advantage of no political conditions being made by Initiative participants, its voluntary character, and the fact that it is not Eurocentric and presented as the South-South form of co-operation. 
China also takes advantage of the ambiguous nature of its Initiative, arguing that it is coherent with the development strategies of individual African countries, such as Kenya's Vision 2030 and the 'Big Four' Agenda of President Uhuru Kenyatta (Xianfa, 2018). This remains in line with earlier commitments by China to Africa which were succinctly expressed by the Chairman of the People's Republic of China, Hu Jintao, who said that China sincerely supports the freedom of African countries to choose their own development path helping them to augment their own potential for development (after: N'Diaye, 2016: 216). However, the BRI originated as a Chinese idea and was not preceded by consultations with potential partners. It is actually used to promote the view that the "economic growth without political liberalization or accountability is not only possible, but advantageous" (Kalathil, 2018: 53).

It is somewhat difficult to determine which African states actually participate in the BRI. Some are embraced by The Belt and Road Initiative directly, thanks to the Maritime Silk Road (MSR), one of the BRI corridors. Consequently, the BRI documents list Djibouti, Sudan and Egypt in the group of initiative participants, although the Republic of South Africa is also included in the maritime co-operation (Vision, 2017). China cannot fail to take into account the most developed country of Sub-Saharan Africa in its agenda. As well as within the BRI, China and South Africa also co-operate within the BRICS, which is making its own attempts to influence African countries, for instance via The BRICS Leaders-Africa Outreach Dialogue Forum (Beijing Declaration, 2018). In 2018, both countries celebrated the $20^{\text {th }}$ anniversary of the establishment of China-South Africa diplomatic relations.

Nevertheless, the geographical range of the MSR is ambiguous and some maps indicate as many as twelve ports in Africa (Kołodko, 2018: 46). Various African countries can be defined as members of the BRI or not, depending on the qualification criteria adopted. There are scholars who take into account the level of Chinese investment and connection to the MSR and include Egypt, Djibouti and Kenya as BRI participants (ZiroMwatela, Changfeng, 2016: 11). The BRI summit (entitled the Belt and Road Forum for International Cooperation) which was held on 14-15 May 2017 in Beijing brought together the Prime Minister of Ethiopia, the President of Kenya and ministerial delegations from Egypt and Tunisia, among others. Another category encompasses the states with the status of BRI Cooperation Countries, namely Morocco, Tunisia, Madagascar and Libya.

The first bilateral agreement with an African country signed under the BRI was concluded with Egypt. In January 2016, the President of Egypt, Abdel Fattah Al-Sisi, signed a Memorandum of understanding on the BRI with China. Both countries are jointly planning to expand the Suez Canal over the next decade, a project to which China has allocated US\$230 million (Bagwandeen, 2017). China State Construction Engineering Corporation (CSCEC) work currently at the construction site of the "Iconic Tower" in Egypt's New Administrative Capital, east of Cairo. As Egypt is struggling with structural unemployment, new jobs are crucial there. The Suez Chinese-Egyptian economic zone alone is planned to create over 10,000 jobs for Egyptians. Many projects that China has launched in Africa in the past employed primarily workers from China, which aroused considerable discontent and doubts among African partners. China has learned from this and now determines the number of 'local' jobs in 
individual agreements. This has weakened counterarguments from the opponents to Chinese investments in Africa and improved the image of China itself.

The operations of China in Djibouti have a specific character. This small country has a strategic location, thereby playing an important role in maritime transport. At present, China is building a military base and container terminal in the port of Dolareh. This will be the first Chinese base abroad, and one of many foreign military bases in Djibouti, where troops are deployed from France, the United States, Japan, Italy, Spain and Germany. The rationale for such initiatives is spelled out in the Forum on ChinaAfrica Cooperation Beijing Action Plan (2019-2021): "The two sides will strengthen exchanges and cooperation in law-based governance, enhance mutual trust and exchanges in this respect, provide legal support and guarantee for China-Africa cooperation and the 'Belt and Road' international cooperation, and work together to improve the existing international legal system" (Forum, 2018). The Action Plan also features provisions on security collaboration: "The African side appreciates China's efforts in implementing the China-Africa peace and security plan, and its support for the operationalization of the African Peace and Security Architecture. China will increase defense and security assistance to Africa, and the two sides will enhance cooperation and strategies and experience sharing in social governance, public security, peacekeeping, cyber security, anti-piracy and counter-terrorism. Fifty security assistance programs will be launched to advance China-Africa cooperation under the Belt and Road Initiative, and in areas of law and order, UN peacekeeping missions, fighting piracy and combating terrorism" (Forum, 2018).

Kenya and Ethiopia are among the informal BRI participants. The Initiative is flexible in that neither its goals nor tools are ultimately fixed, and the principles of participation are not precisely defined, which may be an advantage as well as the source of doubts and reservations about its transparency and settlement procedures. Kenya can be considered an actual BRI participant due to the new Mombasa-Nairobi railway, the largest infrastructure investment since the country gained independence. The railway was built and financed by the Chinese entities which now manage it. It is planned to expand to the border with Uganda in the future. Theoretically, this railway can offer a connection with the Indian Ocean to countries such as Rwanda, Burundi and the Democratic Republic of the Congo, thereby increasing the geographical scope of the BRI. According to Liu Xianfa, the Chinese ambassador in Kenya, this investment created 46,000 local jobs, reduced the cost of transport by $40 \%$ and increased Kenya's GDP by $1.5 \%$ (Xianfa, 2018).

China is Kenya's largest trade partner, largest foreign investor and largest contractor. Another argument in favour of recognising Kenya as a BRI participant is the fact that some projects, such as the modernisation of the port in Mombasa, the construction of a new port in Lamu, and the construction of a pipeline from Kenya to South Sudan, can be declared to be part of the BRI at any moment. China's operations in Kenya are not restricted to infrastructure and trade, however. In 2012, China Central Television (CCTV) opened a branch in Nairobi and China Daily - an English-language daily newspaper owned by the Communist Party of China - launched an African edition, published in Nairobi. In 2017, this international network was renamed 'China Global Television Network' (CGTN), and its African channel, which broadcasts in English, 
'CGTN Africa.' There are no geographical restrictions, and the branches in Lagos, Cairo and Johannesburg report to the headquarter in Kenya.

South Sudan is another potential participant in the BRI. The youngest state in Africa relies heavily on oil extraction. Oil generates $60 \%$ of its GDP and the vast majority of budget revenues, making South Sudan one of the most oil-dependent countries in the world. Oil is practically the only export product, imported mainly by China at a high cost for South Sudan which is generated by the transit through Sudan (US\$ 25 per barrel), where the only pipeline enabling oil to be exported from the south exists. This encourages South Sudan to co-operate with China, which would welcome an alternative new pipeline across Uganda and Tanzania in light of tensions between South Sudan and Sudan, which China views as a threat to secure oil supplies.

In July 2018, President Xi Jinping visited Senegal, Rwanda, South Africa, and Mauritius. His visit resulted in the conclusion of further agreements which were partly related to the BRI; 15 bilateral cooperation agreements with Rwanda and an agreement for future Belt and Road Cooperation with Senegal were signed, the first time a country in western Africa had officially joined the Initiative. Foreign Ministry spokesperson Geng Shuang stated: "Lying in the most western part of the African continent, it is a key extension of the Belt and Road" (Foreign Ministry, 2018). Senegal is becoming China's bridgehead in western Africa. It has already been decided that the 8th Forum on China-Africa Cooperation (FOCAC) Ministerial Conference will be held in Senegal in 2021 (Beijing Declaration, 2018). It also supports the thesis that the BRI might develop further.

China gained another success in Africa when on $3^{\text {rd }}$ September 2018, China and Mauritius, in the presence of Premier Li Keqiang and Mauritian Prime Minister Pravind Jugnauth, finalised negotiations, which had begun in December 2017, on a bilateral free-trade agreement. When it is signed, the deal will be the first of its kind between China and an African partner. China is the largest exporter to Mauritius and the second largest foreign investor (after France). Mauritius can hardly be isolated from the BRI due to its geographical location but has a long tradition of good relations and trade with India. Therefore, it would prefer not to participate in the BRI officially, and not to take an unambiguous position backing either China or India, which strongly opposes the BRI.

On $1^{\text {st }}$ January 2018, a new Addis Ababa-Djibouti railway line began commercial operations. Chinese banks loaned US\$ 3.3 billion for its construction, making it the largest of China's projects in Africa in terms of financial engagement. In the future, this railway line may be extended to reach South Sudan. Ethiopia's favourable attitude to the Chinese development model is sometimes attributed to the socialist path taken by Ethiopia in the past (Kiedy Afryka, 2018). A number of countries in Sub-Saharan Africa tried to implement their own versions of socialism in the past, under the common name of 'African socialism.' It is more justifiable to conclude that the Chinese model offers a development scenario which is effective and at the same alternative to western model, which turned out to be insufficiently effective in Sub-Saharan Africa. The most frequent model implemented in the past was the centrally planned economy and industrialisation model of the USSR. At present, this has been replaced by the Chinese model, which has been spectacularly successful in curbing extreme poverty in China. 
Ethiopia is one of the biggest beneficiaries of Chinese development aid granted to Africa, which is another reason for Ethiopia's friendly attitude to China. China has considerably increased the level of its Official Development Assistance (ODA). The list of the ten biggest beneficiaries of ODA from the PRC features seven African states which collectively received US\$23.3 billion in ODA from China between 2000 and 2014 (AidData):

1. Cuba 6.7,

2. Ivory Coast 4.0,

3. Ethiopia 3.7,

4. Zimbabwe 3.6,

5. Cameroon 3.4,

6. Nigeria 3.1,

7. Tanzania 3.0,

8. Cambodia 3.0,

9. Sri Lanka 2.8,

10. Ghana 2.5.

The same holds true for the number of aid projects. Seven out of ten states where the biggest number of Chinese development projects have been launched are in Africa (AidData):

1. Cambodia 168 projects,

2. Pakistan 121 projects,

3. Zimbabwe 120 projects,

4. Angola 110 projects,

5. Sudan 108 projects,

6. Tanzania 101 projects,

7. Ghana 95 projects,

8. Kenya 89 projects,

9. Ethiopia 88 projects,

10. Sri Lanka 86 projects.

China's development aid is a part of its foreign policy. A new China International Development Cooperation Agency (CIDCA) was established in March 2018. This reorganisation of administration may be related to the BRI. In April 2018, the first director of CIDCA, Wang Xiaotao, was appointed. He has been involved in promoting the BRI in China and has negotiated with countries such as India, Laos, Pakistan, Serbia, Singapore, and Thailand on transport initiatives linked to the Initiative. In the opinion of observers, CIDCA, "which will take over foreign-aid work currently overseen by the foreign affairs and commerce ministries, is likely to focus on advancing the BRI, and to more fully leverage foreign assistance as a component of diplomacy" (Kalathil, 2018: 54). Whereas China rejects the concept of political conditionality in development aid, which enjoys very good reception in many African countries and is a challenge to many Western donors (Koch, 2015: 97), this is not to say that China has abandoned policy objectives altogether.

China is Sub-Saharan Africa's largest trade partner and definitely the largest source of infrastructural investment. The increase in the importance of trade exchange with China for Africa has increased gradually. 
Figure 1. Distribution of Africa's trade, 2000-2016

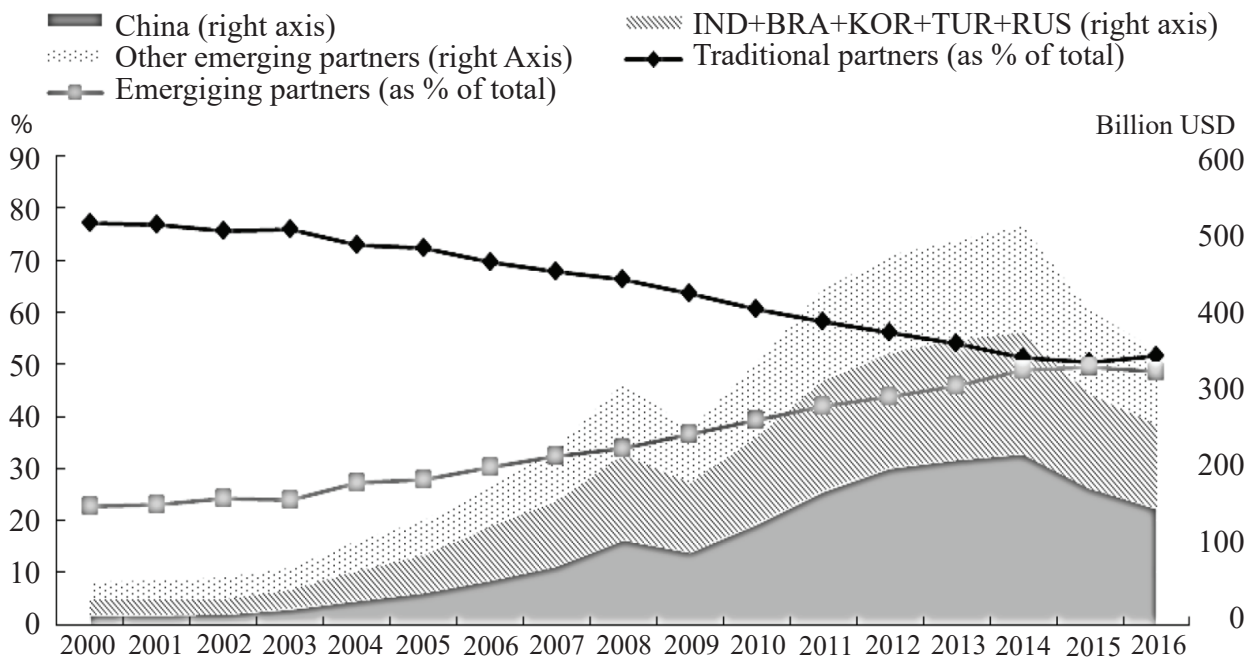

Note: India (IND), Brazil (BRA), Korea (KOR), Turkey (TUR), and Russia (RUS). Trade is the sum of Africa's exports and imports.

Source: AUC/OECD, Africa’s Development Dynamics, 2018.

Currently, China is Africa's largest country trade partner - accounting for $16.3 \%$ of Africa's total trade in 2015 and 11.9\% in 2016 (African, 2017: 11). Africa's largest regional trade partner is the European Union, accounting for $43.2 \%$ of Africa's total trade in 2015 and 38.9\% in 2016 (African, 2017: 11). China's foreign trade balance is positive. According to the statistics by China Customs, in 2017, the value of Chinese-African trade amounted to US $\$ 170$ billion, and China's exports to Africa reached US\$94.74 billion; China's imports from Africa reached US\$75.26 billion; and the trade surplus was US\$19.48 billion (Statistics, 2018). There are only five states in the region with a positive trade balance with China. The structure of trade is not

Figure 2. Trade composition in Africa, 2016
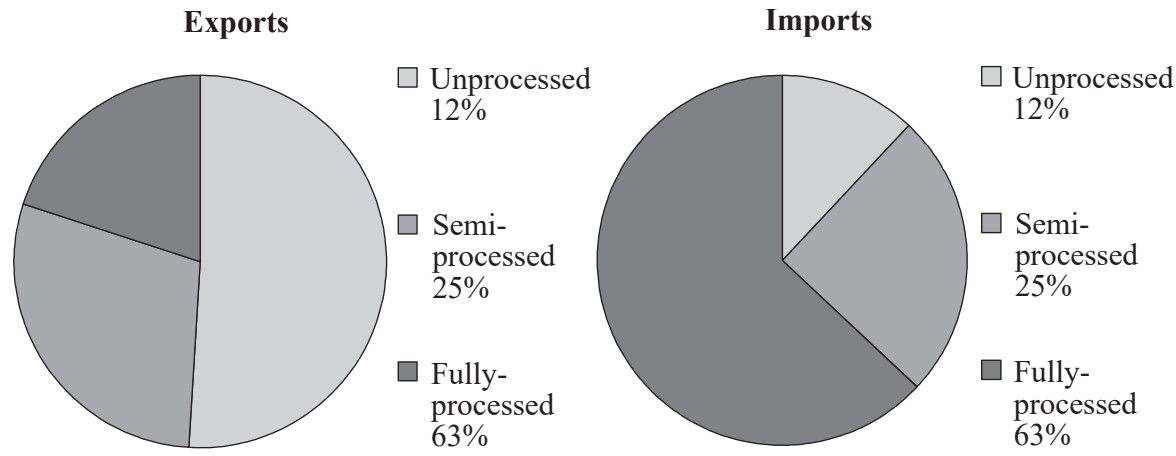

Source: UNCOMTRADE (database). 
advantageous for Africa, either. "Fuel and metal and mineral products account for 70 percent of sub-Saharan African exports to China whereas the majority of sub-Saharan Africa's imports from China are manufactured goods, followed by machinery" (Chen, Nord, 2017: 1).

This structure of trade makes trade conditional on economic growth in China, which is particularly visible in the case of sub-Saharan African commodity exporters. Their revenues strongly rely on the global prices of raw materials. The drop in the value of Chinese-African trade in 2015-2016 resulted from the deceleration of Chinese economy and lower prices for raw materials.

Figure 3. China-Africa Trade

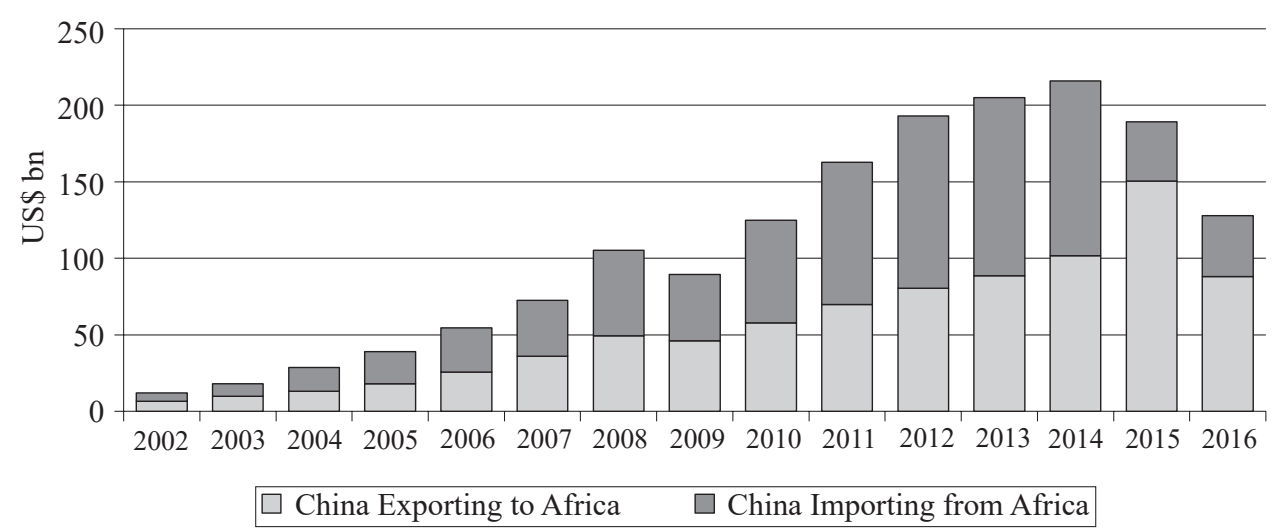

Source: China Africa Research Initiative.

There are several reasons why the BRI has been focused on infrastructure investments:

- "strong demand from countries overcoming infrastructure bottlenecks and improving connectivity, $[\ldots]$

- building infrastructure sooner rather than later could facilitate trade at lower cost, [...]

- building bottleneck-releasing infrastructure as a countercyclical measure could boost aggregate demand and long-term productivity" (Lin, Wang, 2017b: 8).

As well as being an outcome of the government's policy, China's investments in Africa are economically justified. "China has proposed to enhance global connectivity by BRI in part because it has demonstrated comparative advantages in building infrastructure, including hydroelectric power stations, highways, ports, railways, and telecom" (Lin, Wang, 2017a: 151). The majority of the most expensive Chinese investments in Africa are related to transport infrastructure, such as the above-mentioned US\$4 billion railway that connects Nairobi with the port city of Mombasa or US\$3.3 billion railway that runs from Addis Ababa to Djibouti's seaside port of Dolareh; and US\$600 million road connecting Gabon's leading seaport (Port-Gentil) with its capital, Libreville; US\$500 million road in Cameroon connecting the port city of Douala with the capital, Yaoundé; US\$320 million ring road around Addis Ababa. 
According to some scholars, the development-oriented character of China's investments is a result of Confucianism, which is why China's capital in developing countries is sometimes named 'patient capital' (Lin, Wang, 2017c) since it is geared towards long-term results produced after ten years or longer. This does not change the fact that the levels of Chinese FDI and the amount of trade turnover depend on economic growth in China. It is not by coincidence that the number of FDI projects in Sub-Saharan Africa dropped in 2014-2015.

Figure 4. Number of Chinese FDI Projects in Sub-Saharan Africa

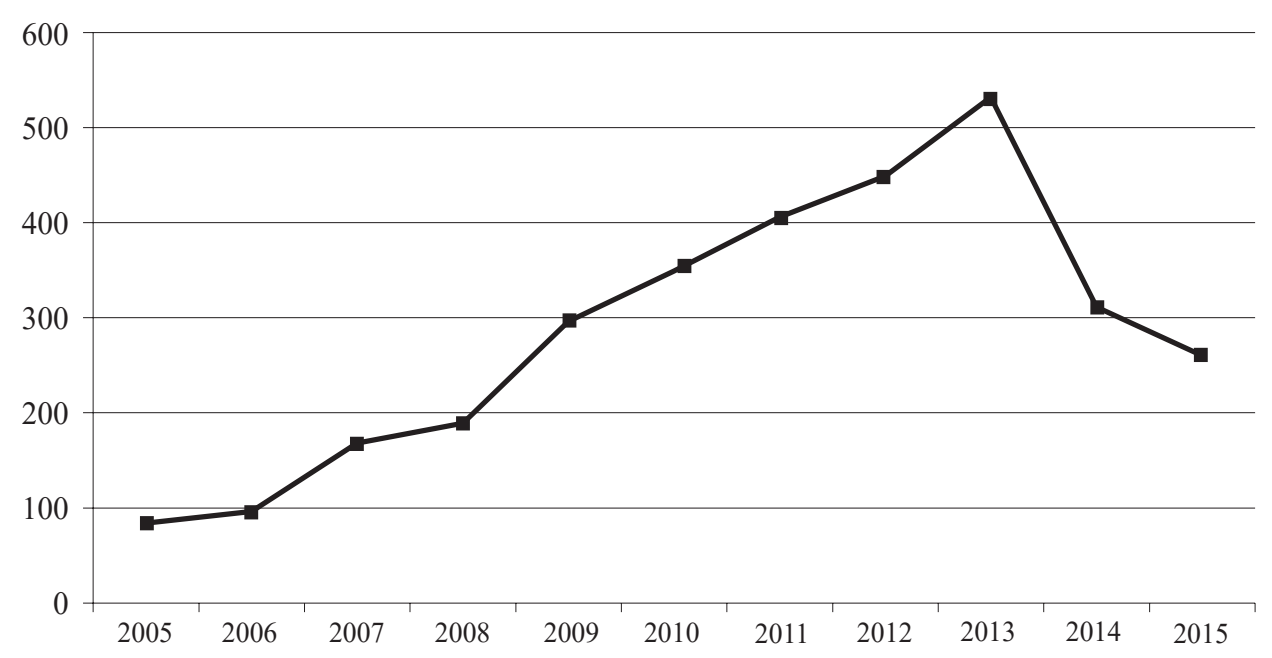

Source: Ministry of Commerce, China.

China's financial engagement in Africa is yet another indicator which has consistently risen in recent years. From 2000 to 2017, the Chinese entities extended US\$143 billion in loans to African governments and their state-owned enterprises (China Africa Research Initiative). Whereas China is not the largest of Africa's creditors, the level of indebtedness of African states may become a problem for China in the future and lead to greater dependence on lenders. "As of the end of 2017, six countries have been assessed to be in debt distress (Chad, Eritrea, Mozambique, Republic of Congo, South Sudan, Zimbabwe)" (Regional, 2018: 11). The problem is more serious than is implied by the number of countries in distress. In April 2018, the International Monetary Fund (IMF) warned that $40 \%$ of "low-income developing countries in the region [Sub-Saharan Africa] are now in debt distress or at high risk of debt distress" (Regional, 2018: 10). Around the same time, IMF Managing Director Christine Lagarde "urged China to prevent its 'Belt and Road' infrastructure plan from becoming a boondoggle that drives up debt in the region" (Bloomberg, 2018).

China's share in the loans and credits extended to African countries is growing. "African government external debt payments have doubled in two years, from an average of $5.9 \%$ of government revenue in 2015 to $11.8 \%$ in 2017; $20 \%$ of African government external debt is owed to China; $17 \%$ of African government external interest 
payments are made to China" (China Africa Research Initiative). African countries with the largest Chinese debt in 2000-2015 are (US\$ billion):

1. Angola - 19.2,

2. Ethiopia - 13.1,

3. Kenya -6.8 ,

4. Sudan -6.5 ,

5. Cameroon -3.7 ,

6. Nigeria -3.5 ,

7. Ghana -3.2 ,

8. $\mathrm{DRC}-3.1$,

9. Congo -2.8 ,

10. Uganda -2.8 (Atkins, Brautigam, Chen, Hwang, 2017).

The majority of the above countries do not have direct ties with the BRI, but this financial data covers a period much longer than the duration of the initiative. On the other hand, Djibouti, for which China is the largest creditor (in terms of percentage of the total debt), is a member of the BRI. Djibouti has been running a highly hazardous credit policy anyway. Over a two-year period, the amount of external debt increased from 50 to $80 \%$ of GDP and "China has provided nearly $\$ 1.4$ billion of funding for Djibouti's major investment projects, equivalent to 75 percent of Djibouti's GDP" (Hurley, Morris, Portelance, 2018: 15-16).

The BRI has practically no geographical constraints, operating in three continents, Asia, Europe and Africa. With reference to the sale of Chinese MA60 airplanes to Central African countries, China emphasises that these are manufactured in Xi' an, the very starting point of the ancient Silk Route (China's, 2018). In this manner virtually all projects implemented in Africa can be connected with the Silk Route. The BRI is a highly ambitious and flexible project: "The Belt and Road Initiative aims to promote the connectivity of Asian, European and African continents and their adjacent seas, establish and strengthen partnerships among the countries along the Belt and Road, set up all-dimensional, multi-tiered and composite connectivity networks, and realize diversified, independent, balanced and sustainable development in these countries" (Vision, 2015).

Justin Yifu Lin suggested that the project be transformed into a 'One Belt, One Road, One Continent' initiative and indicated its strategic goals: "The core of the 'One Belt and One Road' initiative, the creation of a Silk Road Economic Belt and 21st Century Maritime Silk Road, is infrastructure construction. China should also include Africa in the initiative and encourage the transfer of its labor-intensive industries to Africa" (Lin, 2015). There are Chinese businesses which are moving their manufacturing to Africa as we speak (Kiedy Afryka, 2018). As in earlier cases of the relocation of industry, this is primarily caused by lower labour costs, but there is more to it; namely China's large overcapacity in construction materials and chance to improve the return ratio of China's huge foreign exchange reserves. According to some documents, the BRI has already embraced the whole of Africa. "The African side welcomes the Chinese side's championing 'the 21st Century Maritime Silk Road', which includes the African continent, and the two sides will promote mutually beneficial cooperation in the blue economy" (The Forum, 2015). 
China is already in possession of the instruments enabling it to co-operate with the whole of Africa. Starting in 2000, the Forum on China-Africa Cooperation (FOCAC) is organised every three years. The declaration adopted during the $6^{\text {th }}$ summit held in Johannesburg in 2015 was an attempt to bind the FOCAC and BRI, which should: "Actively explore the linkages between China's initiatives of building the Silk Road Economic Belt and 21st Century Maritime Silk Road and Africa's economic integration and sustainable development agenda, and seek more opportunities to promote common development and realize our common dreams" (Declaration, 2015). This was accompanied by financial declarations. China pledged at the 2015 FOCAC to double the financing package for Africa to \$60 billion over 2016-2018 (Chen, Nord, 2017: 21). In January 2015, China signed a Memorandum of understanding with the African Union (AU), which is line with the principal tenets of the BRI and concerns the development of transport infrastructure.

The Declaration adopted at the $7^{\text {th }}$ Summit of FOCAC, held in Beijing on $3^{\text {rd }}-4^{\text {th }}$ September 2018, is even more pronounced with respect to the BRI than the 2015 Declaration: "Africa, being part of the historical and natural extension of the Belt and Road, has been an important participant in this initiative. The cooperation between China and Africa under the Belt and Road Initiative will generate more resources and means, expand the market and space for African development, and broaden its development prospects. We agree to form a strong synergy between the Belt and Road Initiative and the 2030 Agenda for Sustainable Development of the United Nations, Agenda 2063 of the African Union (AU), as well as the development strategies of African countries. The closer connectivity in policy, infrastructure, trade, finance and people-to-people ties, strengthened industrial capacity cooperation under the Belt and Road Initiative, and greater cooperation in the planning of African infrastructure and industrial development will lend new impetus to the win-win cooperation and common development between China and Africa" (Beijing Declaration, 2018). Additionally, FOCAC participants - the Heads of State, Government and Delegations of the People's Republic of China and 53 African countries, and the Chairperson of the African Union Commission (AUC) - agreed to make the Forum a major platform for Chinese-African cooperation under the BRI (Beijing Declaration, 2018).

The importance of the BRI was also stressed by the following provision of the FOCAC Action Plan (2019-2021): "The two sides believe that Africa is an important partner in Belt and Road cooperation, and pledge to leverage the strengths of the Forum and support China and Africa in jointly building the Belt and Road" (Forum, 2018). China repeated its far-fetching financial declarations during the Forum. The US\$60 billion pledge by President Xi Jinping during FOCAC consists of:

- US\$20 billion of credit lines;

- support for the setting up of a US\$10 billion special fund for development financing;

- US\$15 billion of grants, interest-free loans and concessional loans to Africa,

- the setting up of a US\$5 billion special fund for financing imports from Africa, and

- at least \$US10 billion investments to happen over next 3 years (Forum, 2018).

These amounts are incomparably larger than those offered or declared by Africa's other partners, such as the European Union or the United States, and are accompanied by political promises: 
- "no interference in African countries' pursuit of development paths that fit their national conditions;

- no interference in African countries' internal affairs;

- no imposition of our will on African countries;

- no attachment of political strings to assistance to Africa; and

- no seeking of selfish political gains in investment and financing cooperation with Africa" (Full text, 2018).

Not only are the two forms of co-operation, FOCAC and BRI, not mutually exclusive for China, but they are actually related. This was exemplified during the talks on $9^{\text {th }}$ Oct. 2018 with Angolan president João Lourenço in Beijing, when Chinese president Xi Jinping said he "expects the two sides to implement the results of the 2018 Beijing Summit of the FOCAC, promote the eight major initiatives unveiled at the summit to realize early progress, and advance the Belt and Road Initiative" (China, Angola, 2018). Theoretically, Angola is in no way related to the Initiative, and yet it is discussed at the highest political level.

China does not neglect soft power instruments either. The essential element to building China's soft power is the promotion of China's culture through the network of Confucius Institutes. Its branches operate in nearly every country in Africa, and in some there are several: two in Egypt, Tanzania, Ghana, Nigeria, Ethiopia and Madagascar each, three in Morocco, four in Kenya and five in South Africa (Confucius Institute). Additionally, some scholars argue that the rationales of the BRI "are deeply rooted in its [China's] thousand year history of Confucianism, which says: 'One who wishes himself to be successful must also help others to be successful; one who wishes to develop himself must also help others to develop" (Lin, Wang, 2017a: 151). Surprisingly, this is also in line with the African approach to community. An African proverb says: if you want to go fast go alone, if you want to go far then go together.

China's self-promotion campaign is not aimed at BRI participants only, or selected subregions, but the whole of the African Continent. The FOCAC Action Plan (20192021) says that "China will continue to support the development of existing Confucius Institutes and Classrooms in Africa and support qualified African educational institutes to apply for the hosting of new Confucius Institutes and Classrooms, and welcomes the inclusion of Chinese language into African countries' national curriculum. China will continue to support Chinese language teaching in African countries by sending more Chinese teachers and volunteers, donating textbooks and teaching materials in Chinese, providing Confucius Institutes scholarships and training more local Chinese language teachers" (Forum, 2018).

Another factor contributing to China enhancing its soft power is the above-mentioned TV channel CGNT Africa. The third, and most controversial pillar of soft power, is winning political influence in democratic states (Pei, 2018: 46). A clear indicator confirming the increased importance of soft power instruments is provided by educational co-operation. The number of African students in China has already exceeded that of African students in the United States or the United Kingdom, as indicated by the following numbers of African students at China's institutes of higher education in successive years:

- $2006-3,737$, 
- $2007-5,915$,

- $2008-8,799$,

- $2009-12,436$,

- $2010-16,404$,

- $2011-20,744$,

- $2012-27,052$,

- $2013-33,359$,

- $2014-41,677$,

- $2015-49,792$,

- 2016 - 61,594 (Chinese Ministry of Education).

The only country that receives more students from Africa than China is France. The 7th Summit of FOCAC also addressed this issue, as promises were made on the part of China to:

- train 1,000 high-calibre Africans;

- provide 50,000 government scholarships;

- provide 50,000 training opportunities for seminars and workshops;

- provide opportunities for 150 African students to receive master's or PhD education in China;

- every year invite 200 African scholars to visit China

- invite 2,000 young Africans to visit China for exchanges, to promote reciprocal visits among young people (Forum, 2018).

Using soft power instruments, China is seeking the strategic goal of improving the country's image in the eyes of global (including African) public opinion, spreading its own narrative and gaining influence on the language and concepts used in public debate. This is a significant dimension of China's activity as it "promotes its own expressions in Chinese to disseminate their true spirit, uses existing Western concepts (e.g., globalisation) and universal values (e.g., rule of law) but with a distorted meaning, and tries to establish its own concepts (e.g., a community of shared destiny) to be acknowledged worldwide" (Szczudlik, 2018: 1). The BRI framework as such is an instrument of soft power enabling China to promote its own concepts and narrative, and alternatives to Western solutions. "It is worth looking at just the word 'initiative.' China highlights BRI as an 'initiative,' not as 'strategy' or 'policy.' In that sense, China is trying to convince others that the concept has no political goals and is not a political tool to exert pressure on others, that it is an open idea, based on the voluntary choice of any country to be part of it" (Szczudlik, 2018: 8). This approach was clearly visible in the opening speech of President Xi at the Belt and Road Forum for International Cooperation, when he said: "First, we should build the Belt and Road into a road for peace. The ancient silk routes thrived in times of peace, but lost vigor in times of war. The pursuit of the Belt and Road Initiative requires a peaceful and stable environment. We should foster a new type of international relations featuring 'win-win' cooperation; and we should forge partnerships of dialogue with no confrontation, and of friendship rather than alliance" (Full text, 2017).

Regardless the numerous successes in Chinese-African co-operation, this intensive process has also included difficult moments that may have an adverse impact on relations. In 2012, a new AU Conference Centre and Office Complex, erected and financed 
by China, was commissioned in Addis Ababa. A certain incident occurred in January 2018 that might confirm the China-centric attitude to relations with Africa. It was detrimental to the climate of co-operation and supported the claims of the mercenary character of China's presence in Africa. Journalists working for the African version of Le Monde found out that the IT department of the AU had discovered that the computer systems installed in the new buildings made overnight connections to servers in Shanghai to send files and recordings from the microphones installed on the walls and furniture (Tilouine, Kadiri, 2018). The Chinese denied this, but the AU changed the entire computer system in its headquarters and rejected China's offer to configure a new system. Nevertheless, this incident has not brought any repercussions from the African side.

The above analysis allows the several conclusions to be drawn. The BRI is so flexible that it can be extended in a relatively simple way and in a short period to other African countries. The BRI is the structuring factor in China's strategic approach to Africa and can give new impetus to Chinese trade, investment and contracts in Africa. The former institutional co-operation framework that encompassed the whole of Africa was very general and did not result in the identification of such concrete sectoral priorities as is the case with the BRI. The Initiative has exerted influence on China's policy in Africa. There is no doubt that the Initiative's core task in Africa is infrastructure connectivity, but one of the tasks proposed for the future is industrial relocation. If this task is accomplished, it may be fundamental for Africa's development. Additionally, many studies confirm that Chinese development aid is more market-driven and more repayable than western aid. This attitude is in line with the BRI, which is a framework for the implementation of many long-term projects which assume a return on investment and the generation of profit.

It must be acknowledged that the new Chinese narrative is attractive for Africa (the campaign 'tell China's stories well'), which is further facilitated by the anti-colonial and equality-driven discourse of China and the fact that it makes no demands in terms of democracy and human rights. The Africans welcome the declarations of respect for their sovereignty and refraining from interference with their domestic matters. Nevertheless, China is pursuing its own policies and priorities, which raises a number of questions on the strategy behind China's presence in Africa, the Chinese model of development and its significance for Africa, and China being active in a variety of fields, including politics, the military, infrastructure, finance, industry, trade and culture.

\section{REFERENCES}

African Trade Report 2017 (2017), African Export-Import Bank, Cairo, https://afreximbank.com/ wp-content/uploads/2017/07/2017-African-Trade-Report.pdf (30.10.2018).

AidData, www.aiddata.org/china (5.05.2018).

Alden C., Alao A., Zhang C., Barber L. (eds.) (2018), China and Africa: building peace and security cooperation on the continent, Palgrave Macmillan, Cham, Switzerland.

Atkins L., Brautigam D., Chen Y., Hwang J. (2017), Challenges of and opportunities from the commodity price slump, CARI Economic Bulletin \#1, China Africa Research Initiative, Johns Hopkins University School of Advanced International Studies, Washington DC: CARI. 
AUC/OECD (2018), Africa's Development Dynamics 2018: Growth, Jobs and Inequalities, OECD Publishing, Paris/AUC, Addis Ababa, https://doi.org/10.1787/9789264302501-en (30.10.2018).

Bagwandeen M. (2017), The African Link in China's OBOR Initiative, "CCS Commentary", 15 may 2017.

Beijing Declaration - Toward an Even Stronger China-Africa Community with a Shared Future (2018), https://www.fmprc.gov.cn/mfa_eng/wjb_663304/zzjg_663340/fzs_663828/ xwlb_663830/t1593686.shtml (30.10.2018).

Bloomberg (2018), OBOR trouble: Now, IMF chief Christine Lagarde sends this big warning to China over BRI, https://www.financialexpress.com/world-news/obor-trouble-now-imf-chief-christine-lagarde-sends-this-big-warning-to-china-over-bri/1130440/ (30.10.2018).

Brautigam D. (2015), Will Africa feed China?, Oxford University Press, New York.

Chinese Ministry of Education, http://www.moe.gov.cn/jyb_xwfb/xw_fbh/moe_2069/xwfbh_2017n/ xwfb_170301/170301_sjtj/201703/t20170301_297677.html (31.10.2018).

Chen H. (2016), China's 'One Belt, One Road'initiative and its implications for Sino-African investment relations, "Transnational Corporations Review", Vol. 8, Issue 3, pp. 178-182.

Chen W., Nord R. (2017), A Rebalancing Act for China and Africa The Effects of China's Rebalancing on Sub Saharan Africa's Trade and Growth, International Monetary Fund, Washington, DC.

Cheng Z., Taylor I. (2017), China's aid to Africa: does friendship really matter?, Routledge, Taylor \& Francis Group, London-New York.

China's MA60 planes serve Central Africa (2018), https://eng.yidaiyilu.gov.cn/qwyw/rdxw/42835. htm (6.05.2018).

China Africa Research Initiative, http://www.sais-cari.org/data-chinese-loans-and-aid-to-africa (10.09.2018).

China, Angola agree to promote ties as presidents meet in Beijing, http://subsites.chinadaily.com.cn/ cidca/2018-10/09/c_280754.htm (30.10.2018).

Confucius Institute, http://english.hanban.org/node_10971.htm (6.05.2018).

Conteh-Morgan E. (2017), The Sino-African Partnership A Geo-Political Economy Approach, Peter Lang Publishing Inc., New York.

Declaration of the Johannesburg Summit of the Forum on China-Africa Cooperation (2015), https:// www.fmprc.gov.cn/mfa_eng/wjdt_665385/2649_665393/t1323145.shtml (30.10.2018).

Foreign Ministry Spokesperson Geng Shuang's Regular Press Conference on July 23, 2018, https:// www.fmprc.gov.cn/mfa_eng/xwfw_665399/s2510_665401/2511_665403/t1579567.shtml (30.10.2018).

Forum on China-Africa Cooperation Beijing Action Plan (2019-2021) (2018), https://www.fmprc. gov.cn/mfa_eng/zxxx_662805/t1593683.shtml (30.10.2018).

Full text of Chinese President Xi Jinping's speech at opening ceremony of 2018 FOCAC Beijing Summit (2018), http://subsites.chinadaily.com.cn/cidca/2018-09/03/c_267910.htm (30.10.2018).

Full text of President Xi's speech at opening of Belt and Road forum (2017), http://www.xinhuanet. com//english/2017-05/14/c_136282982.htm (30.10.2018).

Góralczyk B. (2018), Wielki renesans. Chińska transformacja i jej konsekwencje, Wydawnictwo Dialog, Warszawa.

Hurley J., Morris S., Portelance G. (2018), Examining the Debt Implications of the Belt and Road Initiative from a Policy Perspective, CGD Policy Paper, Center for Global Development, Washington, DC, https://www.cgdev.org/publication/examining-debt-implications-belt-androadinitiative-policy-perspective $(30.10 .2018)$. 
Kalathil S. (2018), Redefining Development, "Journal of Democracy", Vol. 29, No. 2, April, pp. 53-58.

Kiedy Afryka wystrzeli w górę. Rozmowa z Reinerem Klingholzem (przeprowadził Michał Kokot), „Gazeta Wyborcza”, 17 maja 2018, p. 8.

Koch S. (2015), A Typology of Political Conditionality Beyond Aid: Conceptual Horizons Based on Lessons from the European Union, "World Development", Vol. 75, pp. 97-108, https://doi. org/10.1016/j.worlddev.2015.01.006 (30.10.2018).

Kołodko G. (2018), Czy Chiny zbawia świat?, Prószyński i S-ka, Warszawa.

Lin J. Y. (2015), Industry transfer to Africa good for all, "China Daily”, 20 January, http://usa.chinadaily.com.cn/opinion/2015-01/20/content_19353085.htm (7.05.2018).

Lin J. Y., Wang Y. (2017a), Development beyond aid: Utilizing comparative advantage in the Belt and Road Initiative to achieve win-win, "Journal of Infrastructure, Policy and Development", Vol. 1, Issue 2, pp. 149-167, doi: 10.24294/jipd.v1.i2.68.

Lin J. Y., Wang Y. (2017b), Going Beyond Aid: Development Cooperation for Structural Transformation, Cambridge University Press, Cambridge, doi: 10.1017/9781316597354.

Lin J. Y., Wang Y. (2017c), New structural economics: Patient capital as a comparative advantage, "Journal of Infrastructure, Policy and Development", 1(1): pp. 4-23, doi: 10.24294/jipd. v1i1.28.

N’Diaye T. (2016), Żółte i czarne. Historia chińskiej obecności w Afryce, Wydawnictwo Akademickie Dialog, Warszawa.

Pei M. (2018), A Play for Global Leadership, "Journal of Democracy”, Vol. 29, No. 2, April 2018, pp. 37-51.

Regional Economic Outlook. Sub-Saharan Africa (2018), International Monetary Fund, Washington, D.C, https://www.imf.org/en/Publications/REO/SSA/Issues/2018/04/30/sreo0518 (30.10.2018).

Stahl A. K. (2017), EU-China-Africa trilateral relations in a multipolar world: hic sunt dracones, Palgrave Macmillan, London.

Statistics on China-Africa Bilateral Trade in 2017, http://english.mofcom.gov.cn/article/statistic/ lanmubb/AsiaAfrica/201803/20180302719613.shtml (30.10.2018).

Szczudlik J. (2016), Trzy lata Jedwabnego Szlaku: sukcesy $i$ wyzwania, „Biuletyn PISM”, nr 73 (1423), 2 listopada 2016.

Szczudlik J. (2018), Tell China's Stories Well: Implications for the Western Narrative, PISM Policy Paper, No. 9 (169), September 2018.

The Forum on China-Africa Cooperation Johannesburg Action Plan (2016-2018) (2015), https:// www.fmprc.gov.cn/mfa_eng/zxxx_662805/t1323159.shtml (30.09.2018).

Tilouine J., Kadiri G., A Addis-Abeba, le siège de l'Union africaine espionné par Pékin, http:// www.lemonde.fr/afrique/article/2018/01/26/a-addis-abeba-le-siege-de-l-union-africaineespionne-par-les-chinois_5247521_3212.html\#wcUlIdZmTC39HHxl.99 (5.05.2018).

Vision and Actions on Jointly Building Silk Road Economic Belt and 21st-Century Maritime Silk Road (2015), https://eng.yidaiyilu.gov.cn/qwyw/qwfb/1084.htm (5.05.2018).

Vision for Maritime Cooperation under the Belt and Road Initiative (2017), https://www.yidaiyilu. gov.cn/wcm.files/upload/CMSydylgw/201706/201706200153032.pdf (5.05.2018).

Wekesa B. (2015), China's Silk Road Economic Belt: African Perspectives and Implications, "African East-Asian Affairs", Issue 1 \& 2, pp. 144-161.

Xianfa (2018), Initiating 'a golden era' for China-Kenya Cooperation, 19 April, https://eng.yidaiyilu.gov.cn/ghsl/wksl/53479.htm (5.05.2018). 
ZiroMwatela R., Changfeng Z. (2016), Africa in China's "One Belt, One Road" Initiative: A Critical Analysis, "IOSR Journal of Humanities and Social Science", Vol. 21, Issue 12, Ver. 1, pp. 10-21.

\begin{abstract}
The research purpose of this paper is to examine the role of the BRI in China-Africa relations and the mutual interdependence between the BRI and other forms of Chinese presence in Africa. In order to attain this goal, the method of analysis of secondary data will be employed regarding concluded agreements, trade exchange, Official Development Assistance (ODA), foreign direct investment (FDI), debt, instruments of soft power and plans for the future. The analysis allows the several conclusions to be drawn. The BRI is so flexible that it can be extended in a relatively simple way and in a short period to other African countries. The BRI is the structuring factor in China's strategic approach to Africa and can give new impetus to Chinese trade, investment and contracts in Africa. The former institutional co-operation framework that encompassed the whole of Africa was very general and did not result in the identification of such concrete sectoral priorities as is the case with the BRI. The Initiative has exerted influence on China's policy in Africa. There is no doubt that the Initiative's core task in Africa is infrastructure connectivity, but one of the tasks proposed for the future is industrial relocation. If this task is accomplished, it may be fundamental for Africa's development.
\end{abstract}

Keywords: Africa, China, Belt and Road Initiative

\title{
AFRYKAŃSKI WYMIAR INICJATYWY PASA I DROGI
}

\section{STRESZCZENIE}

Celem tego artykułu jest zbadanie roli Inicjatywy Pasa i Drogi (Nowego Jedwabnego Szlaku - BRI) w stosunkach między Chinami i Afryką oraz wzajemnej zależności między inicjatywą BRI a innymi formami chińskiej obecności w Afryce. Aby osiągnąć ten cel, zastosowano metodę analizy danych wtórnych dotyczących zawartych umów, wymiany handlowej, oficjalnej pomocy rozwojowej (ODA), bezpośrednich inwestycji zagranicznych (FDI), długu, instrumentów miękkiej siły i planów na przyszłość. Analiza pozwala wyciągnąć kilka wniosków. Inicjatywa BRI jest tak elastyczna, że może stosunkowo łatwo i szybko zostać rozszerzona na inne kraje afrykańskie. Inicjatywa BRI jest czynnikiem kształtującym strategiczne podejście Chin do Afryki i może nadać nowy impuls chińskiemu handlowi, inwestycjom i kontraktom w Afryce. Dawne ramy współpracy instytucjonalnej, które obejmowały całą Afrykę, były bardzo ogólne i nie doprowadziły do określenia takich konkretnych priorytetów sektorowych, jak ma to miejsce w przypadku inicjatywy BRI. Inicjatywa wywarła wpływ na chińską politykę w Afryce. Nie ulega wątpliwości, że głównym zadaniem Inicjatywy w Afryce jest integracja infrastruktury, a jednym z zadań zaproponowanych na przyszłość jest relokacja przemysłowa. Jeśli plany te zostaną zrealizowane, mogą mieć fundamentalne znaczenie dla rozwoju Afryki.

Słowa kluczowe: Afryka, Chiny, Inicjatywa Pasa i Drogi 